\title{
Assessment of components of crack users' attention network
}

\author{
Avaliação de componentes da rede para o atendimento a usuários de crack \\ Evaluación de componentes de la red para atención de los usuarios de crack
}

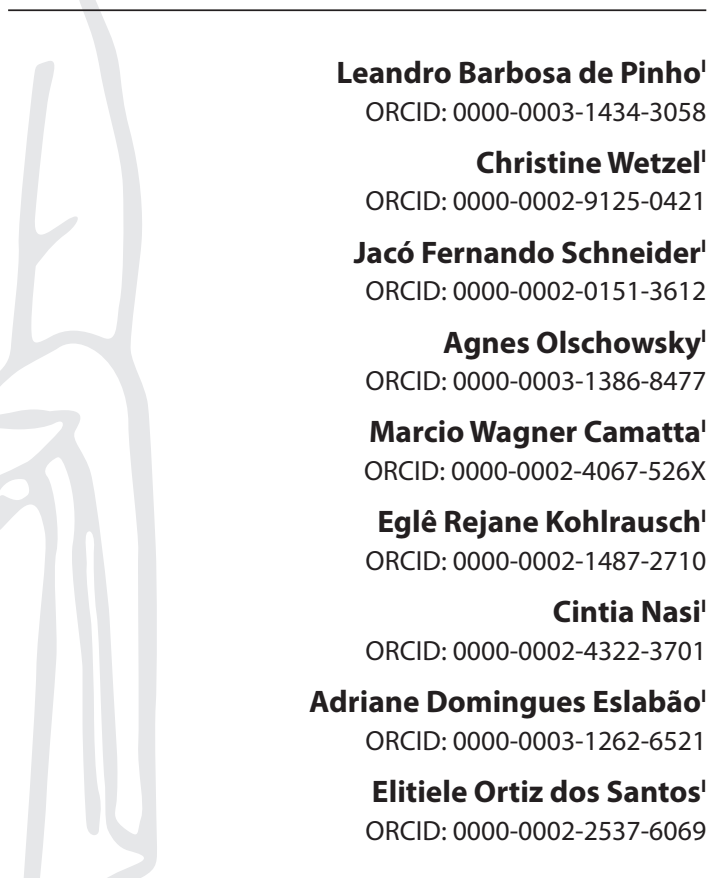

'Universidade Federal do Rio Grande do Sul. Porto Alegre, Rio Grande do Sul, Brazil.

How to cite this article: Pinho LB, Wetzel C, Schneider JF, Olschowsky A, Camatta MW, Kohlrausch ER, et al. Assessment of components of crack users' attention network.

Rev Bras Enferm. 2020;73(1): e20170835. doi: http://dx.doi.org/10.1590/0034-7167-2017-0835

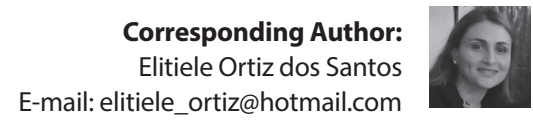

EDITOR IN CHIEF: Antonio José de Almeida Filho ASSOCIATE EDITOR: Hugo Fernandes

\section{ABSTRACT}

Objective: Assess components of the Psychosocial Attention Network (RAPS) in crack user care in a Rio Grande do Sul municipality. Method: Qualitative study based on Fourth Generation Evaluation. Data collection occurred in 2014, through participating observation and interviews based on the Hermeneutic-Dialectic Circle. Ten uses, eleven family members, seven managers and eight workers at a Psychosocial Attention Center participated. The Constant Comparative Method was used for data analysis. Results: Difficulties were observed in the network articulation with the general hospital, due to prejudice and the lack of structure of the team. SAMU's (Mobile Emergency Care Service) dependence on the Military Brigade for the service indicates a frailty of the network. The need to re-think the way therapeutic farms operate in the network is a consensus. Conclusion: RAPS is being implemented and its concretization depends on the involvement of professionals, managers and social control of users and family members.

Descriptors: Crack Cocaine; Mental Health; Mental Health Services; Health Care Reform; Comprehensive Health Care.

\section{RESUMO}

Objetivo: Avaliar componentes da Rede de Atenção Psicossocial (RAPS) no cuidado ao usuário de crack em um município do Rio Grande do Sul. Método: Estudo qualitativo, baseado na Avaliação de Quarta Geração. A coleta de dados ocorreu em 2014, através de observação participante e entrevistas, com base no Círculo Hermenêutico-Dialético. Participaram dez usuários, onze familiares, sete gestores e oito trabalhadores de um Centro de Atenção Psicossocial. O Método Comparativo Constante foi adotado para a análise dos dados. Resultados: Foram identificadas dificuldades na articulação em rede com o hospital geral devido ao preconceito e falta de estrutura da equipe. A dependência do SAMU na Brigada Militar para realizar atendimentos aponta uma fragilidade da rede. Há consenso sobre a necessidade de repensar o modo como as fazendas terapêuticas operam na rede. Conclusão: A RAPS está em implementação e sua efetivação depende do envolvimento dos profissionais e gestores, e do controle social de usuários e familiares.

Descritores: Cocaína Crack; Saúde Mental; Serviços de Saúde Mental; Reforma dos Serviços de Saúde; Assistência Integral à Saúde.

\section{RESUMEN}

Objetivo: Evaluar los componentes de la Red de Atención Psicosocial (RAPS) en la atención de los usuarios de crack en una ciudad de Rio Grande do Sul. Método: Investigación cualitativa basada en la evaluación de cuarta generación. La recolección de datos se produjo en 2014, a través de la observación participante y entrevistas, basadas en el Círculo Hermenéutico-Dialéctico. Participaron diez usuarios, once familiares, siete gerentes y ocho trabajadores de un Centro de Atención Psicosocial. El Método Comparativo Constante fue adoptado para el análisis de datos. Resultados: Se identificaron dificultades en la articulación de la red con el hospital general debido a los prejuicios y la falta de estructura del equipo. La dependencia del Servicio Móvil de Atención de Emergencia (SAMU) en la Brigada Militar para proporcionar servicio demuestra una debilidad de la red. Existe consenso sobre la necesidad de repensar la forma en que operan las granjas terapéuticas en la red. Conclusión: La Red de Atención Psicosocial se está implementando y su implementación depende de la participación de profesionales y gerentes, y del control social de los usuarios y sus familias.

Descriptores: Crack Cocaína; Salud Mental; Servicios de Salud Mental; Reforma de los Servicios de Salud; Atención Integral de Salud. 


\section{INTRODUCTION}

In the Brazilian scenario of the last 30 years, it has been remarkable the varieties of transformations and advances in mental health assistance. Previously focused on the Psychiatric Hospital, this type of care is currently practice through a network of out-of-hospital mechanisms. In this model, there is need of partnership among the different levels of care, prioritizing territorial and community actions ${ }^{(1)}$.

The management of networks is a trend in health systems worldwide, in order to improve services quality, make resources in health territories more efficient and expand the access to the actions. The difference in the composition of these networks is in the management process adopted by each country, that is, a democratizing and participative tendency, intended to guarantee full and equal access, or to seek a rationalizing efficiency by means of focused actions based on the system's managerial modernization ${ }^{(2)}$.

In Brazil, the management in network of drug users' care came along with an intense debate. Since drug use is considered a complex phenomenon, involving multiple factors associated to the individual and the context, it is not possible to build or structure a comprehensive care without participation of different mechanisms. For that matter, since 2003, the Ministry of Health has prioritized the work in network for drug users' care. It is widely acknowledged that the consumption of psychoactive substances is a public health problem that should be approached from the interface between distinct sectors of civil society. As strategies to address the issue, Brazil defined the Damage Reduction Policy, territory care model, establishment of networks and the inter-sector character ${ }^{(3)}$.

The Psychosocial Attention Network (RAPS) arises in this context for people under psychic suffering and with needs resulting from the use of crack, alcohol and other drugs. Among the objectives of RAPS, are the expansion of access to psychosocial attention, warranty of articulation and integration of points of attention in health networks in the territory, qualifying the care by means of reception, continuous follow-up and attention to emergencies ${ }^{(4)}$. RAPS implantation represented an advance in mental health care, since it included crack, alcohol and other drugs users as target public of actions, and proposed the work in network institutionally, placing to professionals the challenge of developing a joint agenda, with planning and execution of integrated actions.

RAPS comprises seven components in which different points of attention are inserted. They are: primary care in mental health, strategic psychosocial attention, urgency and emergency attention, transitory residential care, hospital care, de-institutionalization strategy and psychosocial rehabilitation strategies ${ }^{(4)}$. RAPS proposal is strategic because these aspects have to work connected to the local/regional reality of the user, in an integrated and decentralized work. The presence of these mechanisms is important, however, it does not ensure the knowledge and complexity of the care per se, and in this context, the level of relationship and interaction between them is much more relevant the their presence alone.

The arise of network care in the context of crack use came strongly connected to the wide mobilization of public opinion and political instances on the social and health problems resulting from this drug consumption. Crack addiction is one of the most serious among the conditions involving problematic consumptions of drugs, due to its almost immediate effects. Most crack users are under social vulnerability conditions, with low schooling, weak family links and work informality ${ }^{(5-7)}$.

Due to that, a process of approximation to crack phenomenon started in Brazil, seeking more understanding and awareness, driving attention to the situation. In 2010, the "Integrated Plan for Facing Crack and other Drugs' was instituted, and was expanded in 2011 by the Program "We can beat crack". There was an effort to unify public policies on drugs, with proposition of more integrated care and treatment. Thus, innovation comes from the incentive to inter-sector network as political strategy ${ }^{(8)}$.

Therefore, in face of these considerations, it is fundamental that the look to the crack user will involve the care network that surrounds him, the services that form this network from the perspective of its players. The recent RAPS implementation is translated into assistance innovations and also helps clear certain doubts and uncertainties in the services routine and the way to operate in network. Investing in this network means to consider and better understand the frailties, limits and potentials of network relations in the territory. Network movements are complex, inherent in the current political, social and cultural conjuncture of Brazilian society, and bring us a new perspective to the understanding of social facts. So, the assessment of these RAPS components is important to strengthen integrated action and reduce the barriers imposed by the mental health work complexity in the care of drug users.

\section{OBJECTIVE}

Assess components of Psychosocial Attention Network in the care of crack users in a municipality of Rio Grande do Sul state. The actions of the General Hospital, the Mobile Emergency Care Service (SAMU), and Therapeutic communities will be discussed in the composition of the network.

\section{METHOD}

\section{Ethical aspects}

It is part of the study "Avaliação qualitativa da rede de serviços de saúde mental para o atendimento a usuários de crack" (Qualitative assessment of mental health service network for care of crack users) (ViaREDE), financed by the National Council for Scientific and Technological Development (CNPq) and Ministry of Health (Public Notice MCT/CNPq 041/2010).

The ethical aspects were guaranteed according to Resolution $n^{\circ} .466 / 2012$, of the Ministry of Health's National Health Council. ViaREDE research was approved by Universidade Federal do Rio Grande do Sul's Ethic Committee, and all participants signed the Informed Consent Form.

\section{Theoretical/Methodological Reference frame / Type of study}

The mentioned study used evaluative and qualitative approach based on the Fourth Generation Evaluation's theoretical-methodological reference frame. It is a constructivist and responsive assessment focused on the evaluation of the needs of stakeholders. This evaluative approach occurs based on routine constructions by the subjects that agreed with the assessment, from the 
perspective of a hermeneutic-dialectic process of interaction and negotiation between the researcher and the stakeholders. The group of interest is represented by persons involved and/or affected by the evaluative process ${ }^{(9-10)}$.

\section{Methodological procedures}

\section{Scenario of the study}

The study was conducted in a municipality of Rio Grande do Sul state. This choice was intentional given its peculiar configuration in terms of wide range and diversification of actions in mental health field. The municipality studied is considered reference in this investment. The research was developed from a Center of Psychosocial Attention - Alcohol and other Drugs (CAPS AD), a service considered strategic for the care of users with issues related to alcohol, crack and other drugs.

\section{Data source}

Thirty six (36) individuals participated in the study, distributed in the following interest groups: 11 family members of users under follow-up at CAPS AD or at other point of the mental health network; 10 users under treatment at CAPS AD due to the use of crack, however with good clinical conditions; eight professionals from CAPS AD and seven managers - five of them members of the Mental Health Collegiate, the General Hospital coordinator and the coordinator of the municipality primary care.

Inclusion criteria for professionals and managers were: at least six month experience in the mental health network and not on vacation or leave in the period of the research data collection.

\section{Data collection and organization}

Data collection was performed in 2013 and 2014, through participant observation and interview. Participant observation totaled 189 hours and its record was made in a field diary. The Consolidated Criteria for Reporting Qualitative Research - COREQ - was used as criterion for data organization.

\section{Phases of the work}

The evaluation process was conducted as follows: (1) field contact, where the research proposal was presented and discussed, moment when the groups of interest agreed to participate in the assessment; (2) organization of the evaluation process, when researchers received the right to enter and performed free observation, in order to get to know the service reality and context, without engaging in evaluation activities; (3) identification of group of interest; (4) development and joint constructions, where interviews were made by means of the hermeneutic-dialectic circle; (5) expansion of joint constructions, where other information and materials were introduced that could contribute to the assessment process; (6) preparation of agenda for negotiation that organized groups' information and constructions to be presented to participants; (7) execution of negotiation, where interviewed person had access to the information obtained in data collection for discussion, debate and clarification on the constructions, with opportunity to change them, in order to reach a possible consensus ${ }^{(9-10)}$.

The interviews were oriented by the hermeneutic-dialectic circle, and occurred as follows: in the assessment process people considered emblematic, with knowledge of the health network, were selected. The first respondent, called R1, was subject to the following question: "talk about the operation of crack users' attention network in the municipality". Then, a pre-analysis of R1 interview was made that led to " $\mathrm{C} 1$ " construction. The interview was applied to respondent R2 who, after answering the question, was invited to make considerations on the themes from the analysis of R1. So, from R2 interview analysis, information appeared not only on his considerations, but also criticisms to the demands and constructions of the first respondent (C1), and other formulation was built with more prepared and sophisticated information, based on two sources (C2). The process is repeated with the other respondents from a given group of interest. The researcher was attentive to the main themes highlighted by the respondent, his values, ideas and conceptions ${ }^{(9-10)}$.

Interviews were performed individually, recorded and transcribed in full. Anonymity and secrecy were respected and participants were identified with the initial letter of the group of interest to which they belonged, followed by the interview order. Workers were identified with letter "E", family members with letter "F", users with letter " $U$ " and managers with letter "G".

\section{Data analysis}

The Constant Comparative Method was used for data analysis. This method considers data collection and analysis are parallel processes, one oriented to the other. And for being a participative assessment proposal, stakeholders interfere with the process ${ }^{(9-10)}$.

After this phase's conclusion, negotiation occurred, moment when the set of questions emerged in each group was presented to all members for them to Express their opinion, add new information, and validate their interpretation by evaluators.

The results were classified in thematic categories, one of them referring to the network articulation. Within this category, three components of the municipality attention network studied were discussed: General Hospital, SAMU and the so called therapeutic communities or farms, addressed in the assessment process by the groups of interest. The experience of users, family members, managers and workers, associated to these points of attention, led to the production of an evaluative text that make possible to re-think RAPS and its challenges from its perspective, which will be presented in this paper.

\section{RESULTS}

\section{General Hospital}

In the assessment process of the mental health network for care of crack users in the municipality, the general hospital was mentioned as one of the network's resources. It is a small size general hospital with beds for psychiatric patients. Despite the importance of these beds in a general hospital, as provided in Brazilian law in the mental health field, the groups of interest 
indicate that the local team shows resistance to serve crack users. For them, there is prejudice by professionals working in this service, which renders difficult the general hospital relation with the other components of the network.

[...] here in the hospital they don't accept drunken people or high. They only say that they should not drink, or get drugged that things get better [...]. (F2)

It is something that takes time, they have to change, and they must be quicker. They curse the guy. It should be like other hospitals to be assisted, quicker. (U3)

[...] even today this relation with the hospital is difficult. Taking the user to the hospital is still a "soap opera", because we get there and go straight to the Emergency room, and many times users are mistreated, and that we know. In other moments we, as a team, go along to avoid these embarrassing issues of prejudice against users [...]. (E2)

Mental health managers indicate that they are seeking means to improve the assistance inside the general hospital, by introducing more qualified personnel for the work with psychosocial attention and seeking more engagement with other RAPS care mechanisms.

We have a lot of problems with the professional that is there receiving this patient, it may be the physician or nurse, but the hospital administration itself is having difficulty to manage that, the problem at the entrance doors that is the emergency, but there are efforts, they are already changing, the very resistant pieces are being replaced, [...] also due to that. (G6)

This dialogue among teams is fundamental. We see effort in these relations because you know, the hospital also has high turnover among professionals [...] we have tried, have improved, but is a daily work because even having a unit for mental health hospitalization, it is not an island, it must be integrated inside the line of care proposed by the hospital. (G1)

\section{Mobile Emergency Care Service}

For the groups of interest, SAMU is a resource that offers little safeguard for urgency care cases. The difficulty is that SAMU needs Military Brigade follow-up to provide care to the crack user in crisis:

I have already called SAMU, and they only go with the help of the Brigade, and so there is a whole story. We were not well assisted [...]. Come on, the Brigade contains and SAMU takes. There is a whole process. (F9)

[...] it happened already, [...], we needed, so there was no CAPS, Saturday or Sunday night, so we had to resort to 192, which is SAMU ambulance, but sometimes there was, other times there wasn't, so, with the brigade they took to the hospital [municipality name], and from the Hospital they sent to the Psychiatric Hospital [psychiatric hospital name], [...] directly [...] it's difficult [...]. (F5)

SAMU participation is understood as fundamental in a network texture. However, what is outstanding is the disjointed way its component operate. On the network forums, where some of the research subjects participate, one can observe the need to demand more effectiveness and commitment from the municipal sphere with this articulation:

[...] the dialogue among teams is fundamental, for us to mature this service [...] it is rare SAMU ambulance that brings to CAPS. [...]. SAMU's general coordinator signed the protocol [...] we must go and say to this coordinator: [...], lets seat with the parties, because, obviously, SAMU is regulated by the state, the regulator doctor calls here and the obey exactly what he is saying. The team must only say to him: "look, take to [CAPS II name], take to AD, take to [the other CAPS II name], take to CAPSi" [...]. Well, that must be better tied [...]. (G1)

I think that after the meeting on the forum, the mental health service called SAMU to talk in the meeting, and after that they started to show up more on the forum, and I think that an interesting partnership indeed started [...]. (E6)

\section{Therapeutic farms}

Therapeutic farms are mentioned in groups of interest as points that integrate the user access to RAPS. However, the care model focused on disciplining users is questioned:

In the farm [...] what they do is physical work. My son ruined his entire spine going down the hill. The clinic where he is now, it works the spiritual, the meetings, they do those normal services. [...]. It is a normal work like you would do at home. (F7)

Many people run away [...] people that can't stand it and there are those that are the indoctrinated with that farm talk, then they come with those 12 steps and they bring it here as an imperative talk for the groups, I think it is important that we pay attention to these talks, and it makes sense for many of them. (E1)

The users are the ones that question most the treatment model in therapeutic farms. For them, it is hard to stand the orthodox routine of prayer and work. Many of them can't stand it or have difficulties to deal with the responsibilities they assume in the internal process of work organization.

Istood there for some eight days and couldn't stand no longer because of the prayer. Because we had to wake up early and go pray. (U3)

It is very complicated because there are many people, many loaded persons and each one tries to override the other. [...] like: they start to obtain position and want to override the others, it ends up by making the person confused, still more for those who have just entered there, just left the street, it is very hard. (U8)

Some of those interviewed considered necessary that these mechanisms are incorporated to the public health network, and that, in addition to offering public and free care to the population, they should be separated from a religious bias.

[...] / think that having more farms that are not paid for and that doesn't need this whole bureaucracy, right? [...]. [user name] is waiting to be called until today [...]. (F9)

I honestly think that there should be a recovery house, but not with religion. Many people think that you go to that recovery, if they 
say it is God, many won't go because they have other religions. Some are drummers, others are catholic. So, it should be by the municipal government, without religion [...]. (U7)

\section{DISCUSSION}

The management of networks for drug users had its implementation strongly questioned by antidrug orientations whose prohibitionist paradigm sees drug use as public security issue, rather than sanitary. The dispute involving right claims and increase in punitive measures for drug users demonstrated a sharp duality: the same networks that care also fence this population, marking the assumption of ambiguity in public actions related to this problem ${ }^{(11)}$.

The imprecision of such actions is reflected in the work of professionals in RAPS, as can be seen in the assessments presented in the assistance and care of drug users in general hospitals. These teams face difficulties to incorporate the assistance to psychiatric emergencies in their work routine, and these challenges seem to increase in cases of assistance to crack users' crises.

Studies in Brazil and other South American countries also indicate prejudice towards psychiatric assistance in general hospitals and emergency care units. Many times the user is seen by the teams as a person without commitment, aggressive, violent, manipulator and resistant to treatment. This perception, associated to the lack of infrastructure, poor training and qualification of teams, generate, in professionals feelings of fear and insecurity in the approach, thus perpetuating the maintenance of asylumlike practices ${ }^{(12-14)}$.

The displacement caused by the leave of cares from psychiatric hospitals to the territory also caused in emergency services a necessary re-discussion of their role in the composition of mental health care networks ${ }^{(15)}$. In these cases, psychiatric emergency care has also led to re-think the clinic, under a new model that could also incorporate the humanization and universality as care premises.

It is considered that the production of care to drug users, and, in this case, crack users, involves essentially the fight against prejudice and stigma in the service and in society. For that matter, workers have the task to be engaged in the change of the conception of the drug user, approximating to peoples'lives ${ }^{(16-17)}$. So, teams should seek knowledge and the improvement of more humanized approaches, which requires more sensitivity to hearing without judgment and to have a look to particularities.

Crack users many times end up being diluted in the cartel of clinic situations. However, psychiatric emergencies resulting from problems with its consumption, like craving and psychomotor agitation, would be secondary aspects in face of the high social and health demand. Psychic suffering and clinical complications make the user seek hospital emergencies must be assisted by health teams in order to ensure the rights to health and access to RAPS.

The assessment process showed an important need in the municipality under study to potentiate spaces and strategies that will bring new designs to the mental health policy. The constitution of a mental health team in the general hospital and a partnership can help not only to demystify the drug user, but also to sustain work processes in the network, ensuring the user access. This articulation requires dialogue, negotiations, agreements with other points in the network, including other sectors of the hospital itself.

Sharing of responsibilities (or shared responsibility) requires this interface, since CAPS is not the sole responsible for assistance to crisis. Despite the difficulties and the need to retake the dialogue with the network many times, the positive aspect of this strategy is the composition and co-building of therapeutic projects that will value the user need and promote assistance without prejudice in the health network.

In this study, another question raised by groups of interest is the form of network articulation of SAMY and Military Brigade in the care of crack users. Participant F9 commented on that. It is evident the need that all health workers are qualified to assist in psychiatric urgencies, assessing, in each case, the real need of Military Brigade in the care.

The Military Brigade presence many times is traumatic for the user and family. For being a service that may involve approach in cases with crime suspicion, some users already had negative experience of repression and violence with the Police. So, professionals working in SAMU services can and should perform assistance with Police power, being prepared to adopt the required measures and call other sectors, when risk situation arise to the team, and not indiscriminately in psychiatric emergencies, as was noticed in this study.

We understand that SAMU strong dependence on the Military Brigade requires deeper discussion, as it increases the user's stigmatization potential. There seems to be a certain confusion of articulating principles when the existing connection of public security and health is detached from the real need to question the urban violence caused by traffic and criminality associated to it. Thus, SAMU fails in assisting mental health emergency and the Military Brigade does not focus on the real needs of fight against drug dealing in the local context.

Moreover, we noticed that the strong stigmatizing content in this relation weakens the user's bonds with family and community. Fearing a repressive approach, the user and family can avoid contact with any health services that have minimum articulation and accept this partnership under these conditions. The reformer role of mental health services and their articulations is present here, that is, to question the dimension of the crisis in mental health and what would be the responsibility of each social sector in planning, assessing and executing actions inside the services and outside them ${ }^{(18)}$.

SAMU, in addition to rendering immediate urgency service, whatever it is, should appropriately redirect the user to the service that is most compatible with his clinical and social conditions. It is known that the care of illicit drugs' users are the main psychiatric occurrences assisted by SAMU. However, it is clear the need of follow-up in a mental health service with broader therapeutic proposals, programs and actions to assist the person and his family ${ }^{(19)}$.

Therefore, the service rendered by SAMU in the municipality studied should advance in terms of articulation and knowledge of the network, in order to provide appropriate referrals to users under psychic suffering and in crisis. Inter-sector forums can be rich spaces for discussion and re-agreement of work flows and processes that will improve network actions ${ }^{(20)}$, which is fundamental for assistance to mental health urgencies and emergencies. 
Another emblematic aspect brought by groups of interest was the actions of therapeutic farms. These services are inserted in the local RAPS as transitory residential attention. Therapeutic farms have been denounced many times with regard to mistreatments and violence practiced, like physical and privacy violation, punishment, torture, exposure to humiliating situations, imposition of religious beliefs, disrespect to sexual orientation, embarrassment to family members during visits, unworthy food, housing and basic sanitation conditions ${ }^{(21)}$.

In this study, the religious content in therapeutic farms appears strong, which, though making sense for some users, is not flexible to the needs and singularities of others. It is also evident a mode of organization that awards the user that keeps abstinence, many times generating conflicts.

The importance of considering religious and spiritual dimension in the process of recovery from disease and chemical dependency is proved as complementary resource to the treatment ${ }^{(22-23)}$. However, what is questioned with regard to therapeutic farms in the Single Health System, is the financing without criticism and public inspection of institutions that impose a religious belief and a moral-based therapeutic project, leaving behind a universal policy that would benefit this whole population. This form of operation by public authorities can undervalue the knowledge of health professionals and threaten the Brazilian society's constitutional secularity ${ }^{(24)}$.

Care to drug users requires support based on technicalscientific knowledge from different areas, acknowledgement of epidemiological, collective health and mental health evidences, with valorization of folk wisdom. The actions of therapeutic farms have proved to be contrary to good practices of care with freedom proposed by the Psychiatric Reform Movement. The fact that they operate with the premise of the subject isolation, apart from family and community reinforces the moralist and indoctrinating character, disregarding social bonds that should be strengthened during treatment, rather than being totally apart.

Somehow, therapeutic farms respond, immediately, to family and users' anguishes that don't find, in public services, answers to their problems ${ }^{(23)}$. As they leave the farm, with a routine built in months of conservative treatment, users largely retake their life histories marked by weak social bonds and vulnerability situations. Reality, tougher than that presented inside the farms' walls, does not help the user and can lead him to relapses.

The Brazilian Psychiatric Reform keeps on defending the need for us to learn to care with freedom in the different scenarios. It seeks to be based on an inter-sector network perspective, with damage reduction, social inclusion in work, school, arts, sports, culture and production of values and new social protagonism, replacing drugs in users' life projects ${ }^{(25)}$.

In this regard we can notice the importance of discussing new treatment modalities, considering drug phenomenon complexity in the Brazilian society. The implementation of strategies or components from the Psychosocial Attention Network that will work as "transitory locations", rather than long-stay places, and that support each other in a broad understanding of the process can be a modern solution to a recurring problem. A rich network is the one capable of tensioning the forces that drive the care to more modern and sophisticated alternatives, focused on the collective construction and valorization of individuals' needs, rather than those tend to the recovery of traditional models already criticized and overcome in the psychosocial field.

\section{Limitations of the study}

The limitations of this study refer to the fact that the assessment process includes only some components and points in the wide Psychosocial Attention Network. Also from the perspective of network care, other players should also be included, like social assistance, education, community, which, for being fundamental in this construction, can and should create approaches closer to strategic services. That because diversified and shared care using different devices provides a more sophisticated look to drug users' social and health needs, expanding the range of actions. For other studies, we suggest the incorporation of these other players, since these groups of interest opinions and assessment on the Psychosocial Attention Network is also interesting from the point of view of the collective construction of care.

\section{Contributions to the public mental health policy}

Technical/political commitments are required in mental health and scientific research with participative focus, since conflicts in the drug field are forms of growth and innovation as well. At the same time, these conflicts are full of initiatives anchored in already obsolete models, focused on discipline, stigmatization and moralization of the user, which renders difficult the broad understanding of the phenomenon. As we heard the different groups of interest (users, family members, managers and workers) opinions on the matter, we considered the study successful. The participative process, while promoting discussion and reflection, also drives necessary changes in crack users' care. Therefore, this study is intended not only to advance the production of knowledge on RAPS dynamics in drug users' care, but also to contribute to strengthen and consolidate assumptions of psychosocial attention in the Single Health System.

\section{FINAL CONSIDERATIONS}

Changes in the way of caring and the creation of new mental health services, in network, that may respond to the complexity of human life care became urgent in the last years. RAPS implementation represented an advance in crack users' care, while considering the complexity of care in the drug addiction field and the different dimensions involved in this process.

It was observed that, in the municipality studied, there are different initiatives and paths to the collective construction of responses to the problems generated by drug abuse in people's lives, representing a concern of the local public authorities. The use of inter-sector forums is a strategic solution for the constitution of collective spaces of agreement and construction of political agendas in mental health field.

However, some challenges were identified for consolidation of a network service. Groups of interest identified difficulties in the articulation with the general hospital, mainly due to resistance, prejudice and lack of structure of the team to assist crack users. They also indicated the strong SAMU dependence on the Military Brigade 
in the care of crack user in crisis. With regard to therapeutic farms, on the other hand, there was consensus on the need to rethink the way they operate in the network, based on discipline, orthodox work routine and prayer, as if they were global responses to all drug users.

The rich universe of the research did not only bring further concerns on the theme, but also re-discussed the role of services in the care of crack users, in terms of assessing how the mental health network is capable of producing the social transformations defended by the psychiatric reform and public policies. RAPS is under implementation and its realization depends on the whole community, the involvement of professionals and social control of users and their families.

\section{REFERENCES}

1. Macedo JP, Abreu MM, Fontenele MG, Dimenstein M. A regionalização da saúde mental e os novos desafios da Reforma Psiquiátrica brasileira. Saude Soc [Internet]. 2017 [cited 2017 Aug 10];26(1):155-70. Available from: http://www.scielo.br/pdf/sausoc/v26n1/1984-0470-sausoc-26-01-00155.pdf

2. Pereira AMM, Lima LD, Machado CV, Freire JM. Descentralização e regionalização em saúde na Espanha: trajetórias, características e condicionantes. Saúde Debate [Internet]. 2015 [cited 2017 Oct 03];39(n.spe):11-27. Available from: http://www.scielo.br/pdf/sdeb/ v39nspe/0103-1104-sdeb-39-spe-00011.pdf

3. Costa PHA, Medeiros AX, Lourdes BP, Silva WMDS, Ronzani TM, Colugnati FAB. Survey of the care network for drug users: an exploratory study. Estud Psicol [Internet]. 2017 [cited 2018 Jun 07];22(2):160-71. Available from: https://www.researchgate.net/ publication/323688976_Survey_of_the_care_network_for_drug_users_An_exploratory_study

4. Ministério da Saúde (BR). Portaria n. 3088, de 23 de dezembro de 2011. Institui a Rede de Atenção Psicossocial. Diário Oficial da União, Brasília: Ministério da Saúde, 2011. [cited 2017 Mar 20]. Available from: http://www.saude.pr.gov.br/arquivos/File/Portaria_3088_Rede_de_ Atencao_Psicossocial.pdf

5. Castro Neto AG, Silva DCN, Figueiroa MS. Main mental disorders in crack-cocaine users treated at Psychosocial Care Centers for Alcohol and Drugs in the city of Recife, Brazil. Trends Psychiatry Psychother [Internet]. 2016 [cited 2018 Jul 08];38(4):227-33. Available from: http://www. scielo.br/pdf/trends/v38n4/2237-6089-trends-38-04-00227.pdf

6. Bastos Fl, Bertoni N. Perfil dos usuários de crack e/ou similares no Brasil. Pesquisa Nacional sobre o uso de crack: quem são os usuários de crack /ou similares do Brasil? quantos são nas capitais brasileiras? [Internet]. Rio de Janeiro: Fiocruz, 2014[cited 2017 Mar 20]. Available from: https://www.icict.fiocruz.br/sites/www.icict.fiocruz.br/files/Pesquisa\%20Nacional\%20sobre\%20o\%20Uso\%20de\%20Crack.pdf

7. Fischer B, Blanken P, Silveira D, Gallassi A, Goldner EM, Rehm J, et al. Effectiveness of secondary prevention and treatment interventions for crack-cocaine abuse: a comprehensive narrative overview of English-language studies. Int J Drug Policy [Internet]. 2015 [cited 2017 Oct 03];26(4):352-63. Available from: http://www.ijdp.org/article/S0955-3959(15)00005-5/pdf

8. Pinho LB, Wetzel C, Schneider JF, Olschowsky A, Camatta MW, Kohlrausch ER, et al. Avaliação dos recursos intersetoriais na composição de redes para o cuidado ao usuário de crack. Esc Anna Nery [Internet]. 2017 [cited 2017 Jul 04];21(4):1-8. Available from: http://www.scielo.br/ pdf/ean/v21n4/pt_1414-8145-ean-2177-9465-EAN-2017-0149.pdf

9. Guba EG, Lincoln YS. Fourth Generation Evaluation. Newbury Park: Sage; 2011.

10. Wetzel C, Kantorski LP. Avaliação de serviços em saúde mental no contexto da reforma psiquiátrica. Texto contexto enferm [Internet]. 2004 [cited 2017 Aug 17];13(4):593-8. Available from: http://www.scielo.br/pdf/tce/v13n4/a12.pdf

11. Martinez MM. A gestão da saúde nos registros: empreendimentos para construir redes. Avá [Internet]. 2016 [cited 2017 Apr 25];26(s/n):17597. Available from: http://www.scielo.org.ar/pdf/ava/n26/n26a07.pdf

12. Hildebrandt LM, Marcolan JF. Concepções da equipe de enfermagem sobre assistência psiquiátrica em hospital geral. Rev Rene [Internet]. 2016 [cited 2017 Oct 02];17(3):378-85. Available from: http://www.periodicos.ufc.br/rene/article/viewFile/3473/2716

13. Barreto MS, Büchele F, Queiroz LA. A atenção prestada aos usuários de substâncias psicoativas em Unidades de Pronto Atendimento por enfermeiros e médicos. Saude Transf Soc [Internet]. 2015 [cited 2017 Oct 02];6(3):62-75. Available from: http://www.redalyc.org/ pdf/2653/265345667008.pdf

14. Ortega LB, Ventura CA. I am alone: the experience of nurses delivering care to alcohol and drug users. Rev Esc Enferm USP [Internet]. 2013 [cited 2017 Jan 20];47(6):1381-8. Available from: http://www.scielo.br/pdf/reeusp/v47n6/en_0080-6234-reeusp-47-6-01381.pdf

15. Yasui S, Luzio CA, Amarante P. Psychosocial care and primary care: life as territory in the field. Rev Polis Psique [Internet]. 2018 [cited 2017 Jun 07];8(1):173-190. Available from: https://seer.ufrgs.br/PolisePsique/article/view/80426/pdf

16. Bard ND, Antunes B, Roos CM, Olschowsky A, Pinho LB. Stigma and prejudice: the experience of crack users. Rev Latino-Am Enfermagem [Internet]. 2016 [cited 2017 Aug 21];24(28):1-7. Available from: http://www.scielo.br/pdf/rlae/v24/0104-1169-rlae-0852-2680.pdf

17. Krawczyk N, Veloso Filho CL, Bastos Fl. The interplay between drug-use behaviors, settings, and access to care: a qualitative study exploring attitudes and experiences of crack cocaine users in Rio de Janeiro and São Paulo, Brazil. Harm Reduct J [ Internet]. 2015 [cited 2017 Oct 04];12(24):1-11. Available from: https://www.ncbi.nlm.nih.gov/pmc/articles/PMC4527230/pdf/12954_2015_Article_59.pdf

18. Willrich JQ, Kantorski LP, Antonacci MH, Cortes JM, Chiavagatti FG. Da violência ao vínculo: construindo novos sentidos para a atenção à crise. Rev Bras Enferm [Internet]. 2014 [cited 2017 Sep 25];67(1):97-103. Available from: http://www.scielo.br/pdf/reben/v67n1/0034-7167reben-67-01-0097.pdf 
19. Almeida PMV, Dell'Acqua MCQ, Cyrino CMS, Juliani CMCM, Palhares VC, Pavelqueires S. Analysis of services provided by SAMU 192: Mobile component of the urgency and emergency care network. Esc Anna Nery [Internet]. 2016 [cited 2017 Oct 03];20(2):289-95. Available from: http://www.scielo.br/pdf/ean/v20n2/en_1414-8145-ean-20-02-0289.pdf

20. Nobrega MPSS, Domingos AM, Silveira ASA, Santos JC. Weaving the West Psychosocial Care Network of the municipality of São Paulo. Rev Bras Enferm [Internet]. 2017 [cited 2017 Jan 28];70(5):965-72. Available from: http://www.scielo.br/pdf/reben/v70n5/0034-7167reben-70-05-0965.pdf

21. Perrone PAK. A comunidade terapêutica para recuperação da dependência do álcool e outras drogas no Brasil: mão ou contramão da reforma psiquiátrica? Cienc Saude Colet [Internet]. 2014 [cited 2017 Sep 28];19(2):569-80. Available from: http://www.scielo.br/pdf/csc/ v19n2/1413-8123-csc-19-02-00569.pdf

22. Zerbetto SR, Gonçalves MAS, Santile N, Galera SAF, Acorinte AC, Giovannetti G. Religiosity and spirituality: mechanisms of positive influence on the life and treatment of alcoholics. Esc Anna Nery [Internet]. 2017 [cited 2017 Apr 27];21(1):1-8. Available from: http://www.scielo.br/ pdf/ean/v21n1/en_1414-8145-ean-21-01-e20170005.pdf

23. DieReda J, Gonçalves J. The Role of Spirituality in Treating Substance Use Disorders. J Psychol Clin Psychiatry [Internet]. 2016 [cited 2017 Jun 08];6(4):1-5. Available from: http://d279m997dpfwgl.cloudfront.net/wp/2017/04/Spirituality-Final.pdf

24. Ribeiro FML, Minayo MCS. Religious therapeutic communities in recovering drug users: the case of Manguinhos, state of Rio de Janeiro, Brazil. Interface [Internet]. 2015 [cited 2017 Oct 02];19(54):515-26. Available from: http://www.scielo.br/pdf/icse/v19n54/en_1807-5762icse-19-54-0515.pdf

25. Yasui S, Luzio CA, Amarante P. From manicomial logic to territorial logic: Impasses and challenges of psychosocial care. J Health Psychol [Internet]. 2016 [cited 2018 May 15];21(3):400-8. Available from: http://hdl.handle.net/11449/177935 